\title{
The Alternative to Perpetual Peace: Britain, Ireland and the case for Union in
}

\section{Friedrich Gentz's Historisches Journal, 1799-1800.*}

James Stafford

Emmanuel College, Cambridge University

jms263@cam.ac.uk

Accepted for publication in Modern Intellectual History, November 2014; appearing in Volume 13, Issue 1 (2016).

Published version online at: http://journals.cambridge.org/action/displayAbstract?fromPage= $=$ online\&aid=10043093 \&fulltextType $=$ RA\&fileId $=$ S1479244315000475

\begin{abstract}
The British-Irish Union of 1801 remains a significant and controversial moment in the bistories of both countries, but understandings of its genesis are restricted in scope. This article seeks to place the Union in a new historical context: the crisis of the European states-system that accompanied the French revolution. It considers the position beld by Union in the critique of Kant's famous essay on "Perpetual Peace" (1795) advanced by one of his most influential students, the publicist and state official Friedrich Gentz. (1764-1832). Gentz, argued that the consolidation of the British state offered a model for the regeneration of European society. Only unitary forms of sovereign authority could exercise the responsible political agency required for the restoration of peace in the wake of the revolution. The decline of small states and composite polities supported the durable civil liberty and commercial development necessary to mankind's moral development in history.
\end{abstract}

On $1^{\text {st }}$ January 1801, the Irish parliament sitting at Dublin, and claiming a heritage stretching back to the twelfth century, ceased to exist. ${ }^{1}$ Through Acts of Parliament passed first at London, then at Dublin, Irish representatives were transferred to the parliament at Westminster, where they legislated with colleagues from England, Wales and Scotland on Irish and British matters down to the revolution of 1916-22. ${ }^{2}$ This Union of parliaments was the institutional arrangement targeted by successive nineteenth century Irish movements for Catholic emancipation, land reform and national

\footnotetext{
${ }^{*}$ This research was made possible by grants from the Arts and Humanities Research Council, the Kurt Hahn Trust, Emmanuel College and the Cambridge History Faculty Doctoral Language Fund. I owe particular thanks to the Maier and Stiegmaier families for accommodating me in Munich. While there I benefited greatly from discussions with Eckhart Hellmuth and Annette Meyer. In Cambridge, John Robertson and Isaac Nakhimovsky were invaluable. Thanks are also due to Duncan Kelly and three anonymous reviewers for their helpful comments.

${ }^{1}$ Claims regarding the parliament's antiquity stretched back at least to the seventeenth century: Patrick Kelly, "Recasting a tradition: William Molyneux and the sources of The Case of Ireland ... Stated (1698)", in Jane Ohlmeyer (ed.) Political thought in seventeenth-century Ireland: Kingdom or Colony? (Cambridge, 2000), 83107.

2 The most comprehensive recent study of the Union's passage is Patrick M. Geoghegan, The Irish Act of Union: a study in bigh politics, 1798-1801 (Dublin, 1999).
} 
independence, and retains its ability to provoke violent controversy in the North. ${ }^{3}$ It terminated the brief period of notional legislative independence enjoyed by the Irish parliament following the constitutional revolution of 1782, the subject of fond remembrance among agitators for Repeal and Home Rule throughout the nineteenth century. ${ }^{4}$ As an organising focus for Irish politics over two centuries, it has been the subject of countless studies within the national framework of Irish historiography. ${ }^{5}$ Yet, perhaps because of its centrality to the more recent histories of both Irelands, many aspects of its inception have been shrouded by its subsequent resonances.

This article seeks to place the British-Irish Union within a new context: the crisis of the European states-system that occurred during the decades following the French Revolution. This redrew the map of Europe by eliminating a broad swathe of earlymodern polities, from the Polish-Lithuanian Commonwealth in the East to the Austrian Netherlands and the Irish Kingdom in the West. ${ }^{6}$ The ideological dimensions of this crisis have received extensive attention over the past two decades, as historians of political thought have turned their attention to problems of international relations, economic competition, and colonialism. ${ }^{7}$ The Revolutionary and Napoleonic decades have been identified as the crucial period for the development of a "European worldview", as well as a foundational era for modern conceptions of geopolitics and international law. ${ }^{8}$ They were also a testing ground for new political languages: historians have chronicled the rise of an "imperial liberalism" that constructed new justifications

\footnotetext{
${ }^{3}$ For an incisive treatment of the long-run political trajectory of the Union, see D. George Boyce, Ireland 1828-1923: from ascendancy to democracy (Oxford, 1992). On the Northern Irish troubles as a conflict of allegiance, Richard Bourke, "Languages of Conflict and the Northern Ireland Troubles", Journal of Modern History, 83 (2011), 544-78.

${ }^{4}$ James Kelly, Prelude to Union: Anglo-Irish politics in the 1780s (Cork, 1992).

5 Alvin Jackson, “Ireland's Long Nineteenth Century of Union”, Journal of Modern History, 86 (2014), $124-$ 41.

${ }^{6}$ These developments are extensively discussed in Paul W. Schroeder, The transformation of European politics, 1763-1848 (Oxford, 1994). Charles Tilly observes of this period that "new states came increasingly to form as consequences of wars among established members of the state system and of the negotiations which ended those wars": Charles Tilly, "Reflections on the History of European State-Making", in C. Tilly (ed.) The Formation of National States in Western Europe (Princeton, NJ, 1975), 3-83, at 46. For a brief attempt to place the Irish Acts of Union in this broader context, see James Livesey, "Acts of Union and Disunion: The Union in Atlantic and European Context", in Kevin Whelan and Daire Keogh (eds.) Acts of Union: The Causes, Contexts and Consequences of the Act of Union (Dublin, 2001), 95-105.

${ }^{7}$ Jennifer Pitts, "Political Theory and Empire", Annual Review of Political Science, 13 (2010), 211-35.

8 Stuart Woolf, "The Construction of a European World-View in the Revolutionary-Napoleonic Years", Past and Present, 137 (1992), 72-101. On the impact of the French revolution on international law and geopolitics, Marc Belissa, Repenser l'ordre europèen 1795-1802: de la sociètè des rois aux droits des nations (Paris, 2006).
} 
for overseas empire, and a "modern" republicanism that recognised capitalism and the territorial state as framing conditions for European politics. ${ }^{9}$

The Prussian philosopher Immanuel Kant (1724-1804) has emerged as a crucial figure in all of these contexts, and particularly for his 1795 essay "Perpetual Peace: A philosophical sketch". In this text, Kant famously suggested that Europe could abandon the devastating cycle of warfare and colonial expansion that had defined the eighteenth century by forming itself into a confederation of republican states, defined by representative government and the constitutional separation of legislative from executive power. ${ }^{10}$ Kant's essay provoked extensive discussion among his contemporaries. ${ }^{11}$ This article considers the position held by the British-Irish Union in the critique of "Perpetual Peace" put forward by one of Kant's most influential students, the publicist and state official Friedrich Gentz (1764-1832). It will offer a detailed reading of the largely unexplored essays on British-Irish Union presented in Gentz's Historisches Journal during 1799-1800, and attempt to site them within the broader context of Prussian and European debates over constitutionalism, international relations, and political economy at the turn of the nineteenth century. ${ }^{12}$

Gentz was recognised by both contemporaries and posterity as one of the most prolific, incisive and cosmopolitan critics of the French revolution, a position that he occupied

\footnotetext{
9 On "imperial liberalism" in Britain and France, Jennifer Pitts, A Turn to Empire: the Rise of Imperial Liberalism in Britain and France (Princeton, NJ, 2005). On "modern" republicanism, see inter alia Biancamaria Fontana (ed.) The Invention of the Modern Republic (Cambridge, 1994); Istvan Hont, Jealousy of Trade: international competition and the nation-state in bistorical perspective (Cambridge, Mass., 2005), 447-52; Michael Sonenscher, "The nation's debt and the birth of the modern republic: The French fiscal deficit and the politics of the revolution of 1789 (part 1)", History of Political Thought, 18 (1997), 64-103.

${ }^{10}$ Immanuel Kant, "Perpetual Peace: A Philosophical Sketch" (1795), in H. S. Reiss (ed.) Political Writings, trans. H. B. Nesbitt, 2nd edn. (Cambridge, 1991), 93-131. For a characterisation of Kant as an "antiimperialist", see Sankar Muthu, Enlightenment Against Empire (Princeton, N.J., 2003), 122-210.

${ }^{11}$ Isaac Nakhimovsky, The Closed Commercial State: Perpetual Peace and Commercial Society from Rousseau to Ficbte (Princeton, NJ, 2011).

${ }^{12}$ Gentz's essays are mentioned in Patrick O'Neill, Ireland and Germany: a study in literary relations (New York, 1985), 84, and briefly summarised in M. A. Bond, "A German View of Anglo-Irish Relations in 1800", Eire-Ireland, 8 (1973), 13-21.
} 
from his rise to fame as the German translator of Burke's Reflections through to his diplomatic career as an aide to Metternich. ${ }^{13}$ His essays on the British-Irish Union reveal a lesser-known side of Gentz's politics: the important role played by Britain as a contrasting model for the reconciliation of the progress of society with the demands of political stability. His essays on the Irish Union were conceived and executed as polemical works of contemporary history (Zeitgeschichte), designed to advance a positive vision of Britain during a critical phase of the French Revolutionary Wars. ${ }^{14}$ They take on a broader significance, however, when considered within the context of Gentz's own essay "On Perpetual Peace" (1800), as well his extensive writings on empire, political economy and constitutional theory. Here, the underlying stakes of Gentz's Irish investigations are revealed. Gentz argued for the regeneration of international society through the consolidation of small states and confederations. The construction of modern commercial monarchies, coexisting in a stable balance of power, emerges as the alternative to contemporary visions of perpetual peace. These would operate under administrative structures that distinguished public deliberation from sovereign decision, rather than implementing a modern republican separation of legislative from executive power. ${ }^{15}$ In this context, Gentz's Irish essays appear both as a case for the benefits of enlightened monarchical government, and as a meditation on the politics of conquest and reform, tailored to his critical account of the condition of the Europe in the wake of the French revolution and the Polish partitions. By reconstructing the position held by the Union of 1801 in Gentz's alternative to perpetual peace, we can learn something about the significance of both to the complex and violent politics of the European continent at the close of the $18^{\text {th }}$ century.

\footnotetext{
${ }_{13}$ Günther Kronenbitter, Wort und Macbt: Friedrich Gentz als politischer Schriftsteller (Berlin, 1994); Harro Zimmermann, Friedrich Gent: die Erfindung der Realpolitik (Paderborn, 2012).

${ }^{14}$ On Zeitgeshichte, see now Iwan-Michelangelo D'Aprile, Die Erfindung der Zeitgeschichte: Geschichtsschreibung und Journalismus zwischen Aufklärung und Vormärz (Berlin, 2013).

15 On the Prussian obsession with sovereign decision-making, see Brendan Simms, The Impact of Napoleon: Prussian High Politics, Foreign Policy and the Crisis of the Executive, 1797-1806 (Cambridge, 1997).
} 


\section{WAR, DEBT AND THE MODERN REPUBLIC}

In recent years, Gentz's writings in defence of Britain's maritime empire have received extensive notice from historians of political thought, who have focused on his internationally recognised 1801 reply to the Napoleonic minister Alexander, Comte d'Hauterive's De l'état de la France à la fin de l'an VIII (1800). ${ }^{16}$ Gentz's writings about British-Irish Union predated d'Hauterive's intervention, but formed part of the same European discussion about the relationships between commerce, constitutional design, and war. His writings on Ireland should be read in the context of his thoroughgoing critique of the modern republican account of the state and international politics advanced by Kant and his Francophone interpreter Charles-Guillaume Théremin. They sought to develop a portrayal of the newly-formed United Kingdom as a counterexample of enlightened monarchical statecraft. ${ }^{17}$

Kant's suggestion that a specific kind of 'republican' constitution offered the best means of disciplining the violent potentialities of state sovereignty was based on his famous description of the "unsocial sociability" (ungesellige Geselligkeit) of man. ${ }^{18}$ In his 1793 essay on "Theory and Practice", he had projected that the escalating economic costs of warfare, rendered insupportable by the modern innovations of standing armies and public debt, would eventually lead to the institution of systems of government in which

\footnotetext{
${ }^{16}$ Friedrich von Gentz, Von dem politischen Zustande von Europa vor und nach der französischen Revoluzion (Berlin, 1801). On the "Gentz-Hauterive" debate, see Murray Forsyth, "The Old European States-System: Gentz versus Hauterive", The Historical Journal, 23 (1980), 521-38; Emma Rothschild, "Language and empire, c.1800", Historical Research, 78 (2005), 208-29; Isaac Nakhimovsky, “The 'Ignominious Fall of the European Commonwealth': Gentz, Hauterive, and the Armed Neutrality of 1800”, in K. Stapelbroek (ed.) Trade and War: The Neutrality of Commerce in the Interstate System (Helsinki, 2011), 177-90.

${ }_{17}$ Gentz's allies in this endeavour included the Genevan exile Francis d'Ivernois. For the Francophone intellectual context to the debate, see Richard Whatmore, Against War and Empire: Geneva, Britain and France in the Eighteenth Century (Princeton, NJ., 2012), 228-270.

18 On Kant's “modern” republicanism, see Nakhimovsky, Closed Commercial State, 22-35.
} 
the people who funded international warfare had "the deciding vote on whether war is to be declared or not". ${ }^{19}$ Kant believed that what he called a "republican" mode of governing, in which the sovereign was constrained to enact the public will through the formal separation of executive and legislative power, could help to ensure that war would never again be a matter for the private vanity and ambition of despotic princes. It was because the internal constitutions of Kant's republican states predisposed them against conflict that it became possible to envisage them signing a permanent peace treaty, even in the absence of a higher supranational authority. ${ }^{20}$ It was in this context that Kant hinted at his hopes for the French revolution: "if one powerful and enlightened nation can form a republic (which by its nature is inclined to seek perpetual peace), this will provide a point for federal association among other states". ${ }^{21}$

While Kant's essay was speculative and occasionally ironic, its subject matter was deadly serious. Over the eleven years of neutrality that separated Prussia's 1795 treaty with revolutionary France and her disastrous defeat at the hands of Napoleon in 1806, the kingdom found itself at the centre of an epochal ideological and diplomatic struggle over the future of the European states-system. ${ }^{22}$ Prussia's position was far from straightforward. For some, endorsement of the French republic could be wholly consistent with a distinctly Prussian form of state patriotism, which took pride in the ordered, enlightened and public-spirited outlook its own absolute monarchy. ${ }^{23}$ Kant's perpetual peace essay had argued that a reigning monarch who embodied the public will could play the part of the revolutionary constituting power outlined by Emmanuel-

\footnotetext{
${ }^{19}$ Kant, "On the common saying: 'This may be true in theory, but it does not apply in practice"' (1793), in Reiss (ed.) Political Writings, 61-93, at 91.

${ }^{20}$ Yvonne Podbielski, "Republics, Morals and Peace: Kant's Perpetual Peace in its Historical Context", (Unpublished Ph.D. thesis, University of Cambridge, 1996), 226.

${ }^{21}$ Kant, "Perpetual Peace", 104.

22 On the background to Prussian neutrality, Philip Dwyer, "The Politics of Prussian Neutrality 1795 1805”, German History, 12 (1994), 351-73.

${ }^{23}$ D'Aprile, Erfindung der Zeitgeshichte, 84.
} 
Joseph Sieyès in his seminal pamphlet What is the Third Estate? (1789). A monarchy could even be the best means of instituting a republican constitution; it could move a state via "gradual reforms" towards its "republican potentiality" without a violent and disorderly process of revolution. ${ }^{24}$

In this context, Kant's conception of modern republicanism as a political system capable of disciplining the violent excesses of princely reason of state could function as a demanding standard for the comparative evaluation of Europe's existing régimes. The possible political implications of this outlook are suggested by a book produced by one of Kant's most ardent Francophone supporters, the Prussian Huguenot diplomat turned Directory propagandist Charles-Guillaume Théremin. Des intérêts des puissances continentales, relativement a l'Angleterre (1795) offered a spectacular example of the alignment of French republicanism and Prussian monarchism against the corrupting commercial influence of Britain. ${ }^{25}$ Théremin's work characterised Britain's power as the enemy of peace in Europe and advocated an alliance of the "continental" powers, under French leadership, to defeat its system of mercantile domination. In claiming to discover "le grand secret d'état de l'Angleterre", he offered an exemplary account of British power as a commercial iteration of princely reason of state, through which the pride and vanity of a self-serving mercantile and ministerial elite had corrupted the British constitution and despoiled Europe and India. ${ }^{26}$ "England" aimed "not at universal monarchy through arms, but at a universal influence through commerce, only employing arms to extend the latter". Through a forceful practice of securing the markets of competitor states in Europe and

\footnotetext{
${ }^{24}$ Kant, "Perpetual Peace", 101.

${ }^{25}$ Charles Théremin, Des intérêts des puissances continentales relativement à l'Angleterre (Paris, 1795). The book's propaganda value is illustrated by its subsequent appearances in German (1795) and Dutch (1796). It seems unlikely that Théremin was familiar with Kant's "perpetual peace" essay when he wrote his book, but the text uses arguments outlined in Kant's earlier essays on "Theory and Practice" (1793) and "Universal History" (1784). On Théremin, see Andrew Jainchill, Re-imagining Politics After the Terror: The Republican Origins of French Liberalism (Ithaca, NY, 2008), 115-22.

26 Ibid., 4-8.
} 
India alike for British products, the state gained access to huge quantities of bullion, which it used to corrupt both foreign princes and the people's representatives at home. The ministry's opposition to parliamentary reform, and its defence of princely government in Europe, stemmed from the same source - a desire to restrict the number of individuals it was necessary to bribe: "she likes to treat with an absolute prince, because there is only one person to win, but she fears free peoples, because a Senate is more difficult to buy than a King; in the same manner, she resists the reform of Parliament at home". ${ }^{27}$ Théremin followed Kant in suggesting that standing armies and public debt, "the means of war, or of preparation for war", could plausibly "give birth to peace". ${ }^{28}$ But until Britain was invaded and its credit destroyed by the capture of London, its "artificial" concentration of unparalleled global resources would retain the capacity to sow dissension among the sovereigns of Europe, and to subsidise the war against republican France. ${ }^{29}$ Théremin thereby identified Britain and its empire as the primary obstacle to the realisation of peace in Europe, and the progress of European civilization. $^{30}$

Britain's capacity to provoke resentment and controversy on the continent remained constant down to the end of the century, and became increasingly salient in Berlin as Prussia was placed under increasing pressure to rejoin the British-led military coalition against France. "The dominant principal of the policy of Europe," Gentz warned the British foreign minister William Grenville in October 1800, "and the dominant principle of all the political calculators and writers, is currently jealousy of British power". ${ }^{31}$ Gentz's defence of Britain's political agency, and his polemics against France, were clearly

\footnotetext{
${ }^{27}$ Ibid., 20-21. All translations from French and German are my own, unless otherwise indicated.

${ }^{28}$ Ibid., 8.

${ }^{29}$ Ibid., 103-09.

${ }^{30}$ Ibid., 117-19.

${ }^{31}$ Historical Manuscripts Commission, The manuscripts of J. B. Fortescue, preserved at Dropmore, 10 vols. (London, 1892), vol. 6, p.375.
} 
designed to undermine Prussian neutrality, a policy he despised. "Those who can and should hinder the pernicious progress of the Revolution," he wrote to the British agent General Stamford, "through their egotistical slumber, and through their shameful cowardice, bear almost as much responsibility for the common disaster, as those who have directly founded or advanced it through their madness and fanaticism". ${ }^{32}$ Gentz's British allegiance was founded on a thorough critique of the political judgement of Kant and the French revolutionaries, as well as on a particular interpretation of Kant's philosophy. His famous 1793 translation of Edmund Burke's Reflections on the Revolution in France (1790) transformed the original's deep critique of the metaphysical category of natural right into a more limited attack on the revolutionaries' attempts to convert theory into practice in the historical conditions of contemporary France. ${ }^{33}$ The Historisches Journal expanded the scope for the debunking of revolutionary "prudence" (Klugheit) to cover European politics as a whole. Through detailed economic and constitutional analysis, it sought to demonstrate the inadequacy of the Francophile vision of perpetual peace, and to uphold the enlightened monarchy and the balance of power as the best available vehicles for the progress of mankind.

Political economy offered the sharpest corrective to Théremin's hopes for the downfall of Britain, and to Kant's speculation that public debt could force European sovereigns into a permanent peace treaty. The inspiration for Gentz's economic analysis was Adam Smith, a figure who he viewed with almost boundless admiration. ${ }^{34}$ His first essay on Ireland, offered in the April 1799 issue of the Historisches Journal, was paired with an

\footnotetext{
32 Paul Wittichen, "Das preussische Kabinett und Friedrich von Gentz. Eine Denkschrift aus dem Jahre 1800", Historische Zeitschrift, 89 (1902), 239-73, at 246.

${ }^{33}$ Edmund Burke \& Friedrich Gentz, Betracbtungen über die französische Revolution, 2 vols. (Berlin, 1794), vol. 1, 84-88. Gentz's position is rather curiously summarised in a diagram at 86. See also Jonathan Allen Green, "Friedrich Gentz's Translation of Burke's Reflections", Historical Journal, 57 (2014), 639-659.

${ }^{34}$ Friedrich Karl Wittichen (ed.) Briefe von und an Friedrich von Gentz, 3 vols. (Munchen, 1909, first pub.), vol. 1, Gentz to Garve, 5th December 1790, 181-2. Gentz's political economy has recently been discussed in connection with that of his friend Adam Müller and rival Friedrich Buchholz in D'Aprile, Erfindung, 18088.
} 
analysis "of the trade monopoly of the English", which argued that Britain's dominance of the colonial trades and manufacturing exports could be attributed to its fairly-earned superiority in productivity and skill, as well as to the recent devastation wrought on its continental rivals by France's revolution and war. ${ }^{35}$ It was ridiculous to claim, as Théremin had done, that British commercial strength was "by its nature" hostile to the interests of its neighbours. Such attitudes arose from jealousy, and failed to acknowledge the general benefits of British industrial progress. "The mere existence of a very rich nation should be treated as an open profit for all the others," Gentz claimed. ${ }^{36}$ "Half of the industry and wealth of Europe would be lost with that of England."37

Nor was it likely that this engine of the European economy would collapse in the near future. Speculation about Britain's imminent bankruptcy had gathered pace in the later 1790s thanks to the propagandising efforts of Thomas Paine, whose Decline and Fall of the English system of Finance (1796) was repeatedly targeted in the analysis of Britain's fiscal system published by Gentz in the autumn of 1799. Adam Smith provided theoretical support for Gentz's claims that inflation, rather than ministerial corruption, explained much of the nominal expansion in British public expenditure since the American war, and that the relationship between the productive capacity of the British economy and the extent of state expenditure was healthy enough to sustain the burden of the ongoing conflict. ${ }^{38}$ But Gentz also challenged Smith, hailing Pitt's revived "sinking fund" - an investment vehicle designed to pay down debt - as the keystone of a mature system of public credit. ${ }^{39}$ Smith and Hume's dire mid-century warnings about the risk of a national

\footnotetext{
35 Friedrich Gentz, "Ueber das Handels-Monopol der Engländer, die wahren Ursachen der Enstehung und die Folgen einer gewaltsamen Vernichtung derselben", Historisches Journal, 1 (1799), 395-439, at 429-31.

${ }^{36}$ Ibid., 403.

${ }^{37}$ Ibid., 435.

${ }^{38}$ Friedrich Gentz, "Ueber den jetzigen Zustand der Finanz-Administration und des Nazional-Reichthums von Großbrittannien", Historisches Journal, 3 (1799), 1-107, at 14-30.

39 The "sinking fund" had first been established as early as 1717 by Walpole and Stanhope. See John Brewer, The Sinews of Power: War, Money and the English State (London, 1989), 99-104.
} 
bankruptcy, which continued to inform German discussions about public debt, were described by Gentz as being based on outdated, annuity-based models of war finance derived from the French system under Louis XV. ${ }^{40}$ "The system, with which these harsh critics was concerned, was not that of today", Gentz observed. "Only a superficial observer can overlook the fundamental transformation in its entire organisation that the last fifteen years have brought about." ${ }^{41}$

The rising productivity of Britain's industrial economy, and her development of new models of war finance, cut away the empirical basis for Kant's repeated claims that fiscal exhaustion would eventually restrict the capacity of modern commercial states to make war. The French republic's failure to secure a "republican" constitution offered further reason to doubt the philosopher's historical prognosis. Gentz argued that the separation of legislative from executive power that Kant had proposed, and that the French constitution of 1795 had attempted to implement, was a dangerous chimera. Only mixed constitutions modelled on those of Britain or America, where the executive also had an ability to propose and veto legislation, would be capable of solving "the great political problem: the combination of unity with separation". ${ }^{42}$ Legislatures needed to be restrained by their executives to guarantee the feasibility of measures passed, while many executive acts took on, de facto, the character of laws. ${ }^{43}$ If separated powers were too independent of one another to co-ordinate effectively, they would function as a "constituted anarchy" until one power took the upper hand. This had been the case with

\footnotetext{
${ }^{40}$ Friedrich Gentz, "Finanz-Administration (Beschluss)", Historisches Journal, 1 (1799), 143-244, at 182-90. While Gentz's prediction that Britain could avoid bankruptcy was borne out by subsequent events, Pitt's sinking fund has generally been regarded by economic historians as a quixotic failure: Boyd Hilton, $A$ Mad, Bad, and Dangerous People? England 1783-1846 (Oxford, 2006), 115-16.

${ }^{41}$ Gentz, "Finanz-Administration (Beschluss)", 182.

${ }^{42}$ Friedrich Gentz, "Darstellung und Vergleichung einiger politischen Constitutions-Systeme die von dem Grundsatze der Theilung der Macht ausgehen”, Neue Deutsche Monatsschrift, 3 (1795), 81-157, at 82.

43 Ibid., 87-88, 118.
} 
the French constitution of the Year III, which the Directory had converted into an executive oligarchy via the Coup of 18 Fructidor. $^{44}$

The Constitution of the Year VIII, under which Napoleon had been named First Consul and subjected only to tokenistic constitutional restraints, marked the final, inevitable reversion of the French state to a form of monarchy. "Now all is wisdom", Gentz wryly observed, "that was called stupidity from 1789 to 1799; everything nonsense and tyranny, that over these ten years was called higher politics and freedom. ${ }^{, 45}$ In the end, however, the dominance of the new Consulate amounted only to a necessary "preponderance, without which a mixed constitution ... can perhaps never survive". ${ }^{46}$ This realisation of the inevitable had come at a huge cost to the progress of European civilisation. Instead of forming a modern republic that sought perpetual peace, Gentz argued that France had actually succeeded in recreating the pathologies of Rome's ancient republicanism, which combined violent civil dissension with ruthless foreign expansion. Modern politics was less durably insulated from reversions to barbarism than Kant had suggested. Referring to Montesquieu's landmark work of philosophical history, the Considérations sur les causes de la grandeur des Romains et de leur décadence (1734), Gentz marvelled at how this "great mind" had "described the future, even as he depicted the past with masterful accuracy". ${ }^{47}$

Given the parlous record of the French republic in securing domestic or international peace, Gentz was relaxed about the accusations levelled by Théremin and others that the British constitution had degenerated into a ministerial despotism. ${ }^{48}$ Britain's regular

\footnotetext{
${ }^{44}$ Friedrich Gentz, "Ueber die Natur and und den Werth der gemischten Staatsverfassungen", Historisches Journal, 1 (1799), 487-98, at 494.

${ }^{45}$ Friedrich Gentz, "Ueber die neue Französische Constituzion (Beschluss)", Historisches Journal, 1 (1800), $317-71$, at 336.

46 Ibid., 356.

${ }^{47}$ Friedrich Gentz, Ueber den Ursprung und Charakter des Krieges gegen die Französische Revoluzion (Berlin, 1801), $186-87$.

${ }^{48}$ Gentz, “Theilung der Macht”, 151-57.
} 
exercise of a unified sovereign power offered a beneficial counterweight to the disorder and rampant militarism that was being forced on Europe by France's flawed separation of powers. Inverting half a century of Swiss, French and German praise for Britain's mixed and balanced constitution, Gentz argued that the genius of the British system was in fact its total fusion of executive with legislative power. ${ }^{49}$ Because government was impossible without a ministerial majority in the House of Commons, the authority of the Crown-in-parliament was, in the end, just as absolute as that of the ruler in a "pure" monarchy: "so hangs the whole security and wellbeing of the state", Gentz observed, "from the justice and wisdom of the King and his ministers". 50

Gentz's essay “'On Perpetual Peace” (1800) was correspondingly withering about Kant's suggestion that republican constitutional reforms could lead to the realisation of his cosmopolitan aspirations, describing it as "an error ... that can be left to its own fate". ${ }^{11}$ It is important to note, however, that the two Prussians shared a remarkably similar position in the context of the broader German debate. Kant's international federation, which preserved the untrammelled sovereignty of its individual members, had always been a pragmatic "negative substitute" for the "positive idea of a world republic". The realisation of this ideal had its share of advocates in the fevered conditions of the revolutionary era, but Kant was not among them. ${ }^{52}$ He suggested only that "an enduring and expanding federation" created by treaties between states was "likely to prevent war". ${ }^{53}$ Unlike the most famous eighteenth century advocate of perpetual peace, the Abbé St. Pierre, he did not suggest that this federation would be governed by shared

\footnotetext{
49 Richard Whatmore, "Etienne Dumont, the British Constitution, and the French Revolution", The Historical Journal, 50 (2007), 23-47; Edouard Tillet, La constitution anglaise, un modèle politique et institutionnel dans la Frances des Lumières, (Aix-en-Provence, 2007); Iain Mcdaniel, "Jean-Louis Delolme and the Political Science of the English Empire", The Historical Journal, 55 (2012), 21-44.

${ }^{50}$ Gentz, "gemischten Staatsverfassungen", 497-98.

${ }^{51}$ Friedrich Gentz, "Ueber den ewigen Frieden”, Historisches Journal, 3 (1800), 711-90, at 788 fn..

52 Alexander Bevilacqua, "Conceiving the Republic of Mankind: The Political Thought of Anacharsis Cloots", History of European Ideas, 38 (2012), 550-69.

${ }^{53}$ Kant, "Perpetual Peace", p.105.
} 
supranational organs of positive law. Kant's essay thereby bypassed various contemporary western and southern German arguments for a new European order modelled on the existing institutions of the Holy Roman Empire. ${ }^{54}$ Kant, Théremin and Gentz mostly avoided explicit reference to the latter in their discussions of the prospects for peace in Europe. At least in 1800, Gentz regarded the Empire as impotent, and treated its downfall as a foregone conclusion. ${ }^{55}$ Like Kant, he saw no possibility for a European superstate or a federal constitution based on positive law. ${ }^{56}$

Gentz's essay on perpetual peace was a less expansive attempt than Kant's to reconcile the moral imperative of universal peace with the hazardous circumstances of contemporary Europe. His thinking owed much to the account of international law given by one of Kant's "sorry comforters", the Swiss jurist Emmerich de Vattel, in his Law of Nations (1756). Gentz upheld Vattel's conception of the balance of power as an instrument for the preservation of European society as a whole, which could exist only in the form of negative community between states, what Gentz called the imperfect civil constitution' of Europe..$^{57}$ The task of contemporary politics was not the establishment of perpetual peace, but the reconstruction of a functioning European society in which international conflict could be reduced to bearable levels. ${ }^{58}$ Gentz's commitment to the principle of international society was evidenced by his horror at Johann Gottlieb Fichte's suggestion that a "closed commercial state" could cut the Gordian knot of international

\footnotetext{
54 On St. Pierre, Podbielski, "Republics, Morals and Peace", 23-8. On the German debate, Wolfgang Burgdorf, "Imperial reform and visions of a European constitution in Germany around 1800", History of European Ideas, 19 (1994), 401-8.

${ }^{55}$ Gentz was later to revise this view on his entry into the Habsburg service. For his condemnation of Napoleon's dissolution of the Empire, see Friedrich von Gentz, Fragments upon the balance of power in Europe (London, 1806).

${ }^{56}$ For Gentz's views on a "federal” constitution for Europe, Gentz, "Ueber den ewigen Frieden", 765-67. It is notable that, in spite of his endorsement of the "origins and principles" of the American revolution, Gentz extended his pessimism about federal constitutions to that of the United States.

${ }^{57}$ Ibid., 775. On Samuel von Pufendorf's conception of "negative" community as a non-contractual form of coexistence under the law of nature, see Hont, Jealousy of Trade, 178.

58 Gentz, "Frieden", 775-77.
} 
competition by separating rival powers from one another. " ${ }^{59}$ "The continuous community among the inhabitants of this earth is the foremost condition of all truly human culture", Gentz declared. "The human species was only insured against any relapse into general barbarism from the moment in which the farthest points were placed in connection by trade and navigation". ${ }^{60}$

In the absence of reliable constitutional mechanisms for eliminating the incentives for conflict among Europe's sovereigns, Gentz mounted a strong defence of the idea of an enlightened reason of state, which he called "true politics". By upholding the balance of power, this sought "constantly to lead and to order the relations between states, so that they attain the greatest possible similarity to a legal civil constitution". He hailed the virtues of the "statesman, in the higher meaning of the word", who navigated the treacherous waters of international politics with firmness and deep knowledge. ${ }^{61}$ The diffusion of the enlightened science of political economy had a special role to play in educating European statesmen in their duty to uphold international society. In the two decades before the French revolution, the spread of liberal economic ideas from the writings of philosophers to the minds of ministers and monarchs had promised "a new era of wisdom, humanity and peace". ${ }^{62}$ But politics, for Gentz, retained its autonomy and prudential character. "If there were a science (Wissenschaft), that taught the means to perpetual peace," Gentz speculated, "so would this be the highest among all the human sciences; since there is no such science, so must we handle with reverence, that which in its fullness founds the most durable possible peace". ${ }^{63}$

\footnotetext{
${ }^{59}$ Nakhimovsky, Closed Commercial State.

${ }^{60}$ Gentz, "Frieden", 747.

${ }^{61}$ Ibid., 762-63.

62 Ibid., 785-86.

63 Ibid., 763.
} 
Gentz was clear that the implementation of this political project would be extremely hazardous in a Europe torn apart by the French Revolution. This he regarded as irreversible: in a 1798 review of Burke's posthumously published Three Memorials on French Affairs (1797), he remarked that the Bourbon position expressed in the "Remarks on the Policy of the Allies" (1793) would strike some readers as "shocking". He questioned Burke's enthusiasm for restoring the old order, suggesting that in 1793 a "calm observer" would already have seen "chasms between the condition of France and such a possibility" ${ }^{64}$ Gentz sought to base his political prescription on what he regarded as the objective requirements of a functional states-system. It was heavily implied that Prussian re-entry into the war on the side of Britain and Austria would be a necessary step towards a durable settlement, and that Prussia and the other continental powers would have to conquer new territories to balance the irreversible rise of France. The direction of his thinking on this point was illustrated by a glowing reference to a work that "deserves to remain for some time the handbook for all thinking statesmen", Dominique de Pradt's La Prusse et sa Neutralité (1800). ${ }^{65}$

The Abbé de Pradt, a French emigré on the cusp of a return to favour as Napoleon's confessor, had argued for the revival of the "Grand Design", a seventeenth century French scheme for the consolidation of the German states, as the key to a durable peace settlement in Europe. His version of the scheme differed in important respects to the policy being implemented along these lines by Talleyrand, d'Hauterive and Napoleon: Prussia was nominated to play the "disinterested" role formerly occupied by France, while the consolidation of the two Netherlands and of northern Italy into new states, rather than the reform of the Holy Roman Empire, would be the keystone of a new

\footnotetext{
${ }^{64}$ Friedrich Gentz, "Rezension: Ueber den neuren politischen Zustand und die Verhältnisse der europäsichen Staaten usw. Aus den hinterlassenen Papieren des engl. Parlaments-Redners Burke”, Minerva, 1 (1798), 5-10, at 7.

${ }^{65}$ Gentz, "Frieden", 737 fn..
} 
European settlement. ${ }^{66}$ Gentz regarded the specifics of de Pradt's plan as worthy, but unequal to the real expansion in French power that had occurred since the Revolution. In the aftermath of the shattering Austrian defeat at Marengo, he offered an assessment of the possibilities was hazier, and somewhat darker: "Since it is now as good as decided, that France will never again be forced back to her old borders, a different system - if one can think without terror, that it perhaps only would be brought about by new acts of violence - must become the constant aim of statecraft". ${ }^{67}$

The outlines of Gentz's "different system" were suggested by a forthright attack on Europe's surviving small states and principalities. In the modern era, these had become a menace to the stability of the continent. Small principalities were endlessly vulnerable to the ambition of larger neighbours or to succession crises, while city-republics were seedbeds of faction, militarism and barbarism. Gentz declared that "half of all the wars, that have torn Europe apart in the last three hundred years, arose from the existence of small states". ${ }^{68}$ He regarded it as a truism that there was an inversely proportional relationship between the number of states in Europe and the possibilities for wars between them: "for the interest of society, considered in its fullest extent, the war of five of six considerable powers is far less destructive than the war of two or three hundred would be". ${ }^{9}$ A policy of conquest and consolidation by the counter-revolutionary powers, rather than the Kantian project for a French-led confederation, offered the best hope for the regeneration of international society and the future of the Prussian

\footnotetext{
${ }^{66}$ Dominique Dufour de Pradt, La Prusse et sa Neutralité (1800), vi-viii, 149-67. On the "Grand Design", Michael Sonenscher, Before the Deluge: public debt, inequality, and the intellectual origins of the French Revolution (Princeton, N.J., 2007), 108-21.

${ }^{67}$ Gentz, "Frieden", 739.

${ }^{68}$ Ibid., 732-34.

${ }^{69}$ Ibid., 735.
} 
monarchy. "Force alone", Gentz declared, "will decide what the future law of nations shall be among the states of Europe". ${ }^{70}$

\section{CONQUEST, COMMERCE AND CIVILIZATION}

Gentz's defence of British policy in Ireland was composed shortly before his reflections on perpetual peace, and tracked these broader views on Europe's future. While offering fresh evidence for the continued vitality of Britain's commercial and political system, they also functioned allegorically, as a model for the consolidation of sovereign authority and the European states-system that Gentz envisaged. "The Union", he declared, "must in a moment, where everything in the political world points to division and dissolution, be the most effective and decisive of all measures salutary to the public that the British government could conceive of', ${ }^{71}$

This presentation of British policy in Ireland as a model for continental emulation would have surprised Gentz's readers, since it conflicted with a German consensus that Britain's rule of Ireland was concrete proof of the danger she posed to neighbouring states. This was not confined to Francophile revolutionaries such as Théremin or the radical Lutheran pastor Andreas Riem, who both deployed the case of Ireland in their polemics against Britain. ${ }^{72}$ The Irish kingdom had burst in to German political consciousness in the decades before the French revolution, spurred by the constitutional revolution of 1782 and the rise in Celtophilia prompted by the Ossian forgeries, which

\footnotetext{
70 Ibid., 789.

${ }^{71}$ Friedrich Gentz, "Ueber die Final-Vereinigung zwischen Großbrittannien und Irrland (Beschluss)", Historisches Journal, 3 (1800), 615-710, at 701.

${ }^{72}$ Théremin, Intérêts, 70-71, Andreas Riem, Reise durch England, in verschiedener, besonders politischer Hinsicht, 2 vols. (Leipzig, 1798), 1:476-7.
} 
played a famously central role in Goethe's Leiden des jungen Werthers (1774). ${ }^{73}$ The lengthy 1784 article on Ireland that appeared in Johann Georg Krünitz's Oekonomische Enclycopädie, one of the major lexika of the Aufklärung, was sharply critical of the role of England's mercantile elite in restricting Irish trade, and condemned the Irish constitution's intolerance against Catholics and Dissenters. ${ }^{74}$ These criticisms proved enduring. The influential journal Minerva, no friend to the French revolution, ran a series of vivid articles chronicling the excesses of British military rule in the wake of the Irish rebellions in the course of 1798 and 1799.

The first priority for Gentz's discussion of Ireland was therefore a defensive re-casting of Irish history that ascribed its widely acknowledged record of violence and division not simply to "England", but to past iterations of the religious and political enthusiasm that animated both the French revolution and the United Irish rising. The political concessions of recent decades, culminating in the Union itself, represented the belated triumph of enlightened statecraft in Britain's government of its Irish colony. This strategy of differentiation required extensive historical research. "He who wishes to judge the Union with expertise", Gentz announced at the start of his first essay on the subject, "must resolve to go back to the early history of the relationship between England and Ireland". ${ }^{75}$ In preparing his writings on Ireland, Gentz gathered a range of books and pamphlets from London and Dublin debating the Union, which he listed in the form of an annotated bibliography. ${ }^{76}$ As Burke's German translator, Gentz was familiar with his major published works on Irish affairs, but the treatment of Irish history in the

\footnotetext{
${ }_{73} \mathrm{O}$ 'Neill, Ireland and Germany, pp.78-83.

${ }^{74}$ Johann Georg Krünitz, "Irrland", in Oeconomische Encyclopädie, oder allgemeines System der Staats-Stadt- Hausund Landwirthschaft, in alphabetischer Ordnung, vol. 30, 242 vols. (Berlin, 1784), 742-63, at 758-59.

${ }^{75}$ Friedrich Gentz, "Plan zu einer engern Vereinigung zwischen Großbrittannien und Irrland", Historisches Journal, 1 (1799), 439-86, at 439.

${ }_{76}$ Friedrich Gentz, "Ueber die Final-Vereinigung zwischen Großbrittannien und Irrland", Historisches Journal, 4 (1800), 500-614, at 604-614.
} 
Historisches Journal also drew important elements from two further sources. ${ }^{77}$ David Hume's History of England (1754-61), which largely recycled older authorities such as Giraldis Cambrensis and John Davies when dealing with Irish matters, was widely available in Germany. ${ }^{78}$ More surprising was Gentz's recourse to the writings of the Orange Order Grand Master Patrick Duigenan (1735-1816), whose exhaustive works on Irish history and the Union were cited with qualified approval in the Prussian's bibliography. ${ }^{79}$

Gentz echoed a trope common to all of these sources when he asserted that the first Anglo-Norman conquest of Ireland in 1172 had been incomplete, motivated by the private interests of feudal adventurers who remained confined to the Pale around Dublin. More distinctive was his condemnation of the Statutes of Kilkenny (1366), a subsequent attempt to shield English settlers from the corrupting influence of Irish customs through a series of proscriptive laws. Where English and French-speaking historians of Ireland, including Burke and Jean-Louis de Lolme, had condemned these for preventing the blending of settler and native that had ultimately resulted from the Norman conquest of England, Gentz's argued that the Statutes, much like Fichte's project for a closed commercial state, obstructed the broader "community of mankind" on which human progress depended. "When any civilised nation subjugates a raw, or less civilised one," Gentz wrote, "so the civilised nation usually imparts the benefits, as reparation for the loss of its independence, that are connected to a higher culture". Under the Statutes of Kilkenny, however, Ireland's English colony had done the

${ }^{77}$ Ibid., 564-65.

78 Günthar Gawlick and Lothar Kreimendahl, Hume in der deutschen Aufklärung. Umrisse einer Rezeptionsgeschichte (Stuttgart-Bad Cannstatt, 1987), 16; Roland Ludwig, Die Rezeption der Englischen Revolution im deutschen politischen Denken und in der deutschen Historiographie im 18. und 19. Jabrhundert (Leipzig, 2003).

${ }^{79}$ Gentz, "Final-Vereinigung", 604.

80 Thomas Leland, The History of Ireland, from the Invasion of Henry II, with a Preliminary Discourse, on the Ancient State of that Kingdom, 3 vols. (Cork, 1775), vol. 1, 329-3, Jean-Louis Delolme, The British Empire in Europe, Part the First (Dublin, 1787), 40-44, Edmund Burke, "Letter to Sir Hercules Langrishe", in R. B. McDowell (ed.) Writings and Speeches of Edmund Burke, vol. 9, 9 vols. (1991 [1792]), 594-640, at 615-16. 
opposite, functioning as "a sort of partitioning wall, that violently closed it off from the rest of the world" ${ }^{81}$

Ireland's exclusion from the advancing European culture of the high Middle Ages had been compounded by the repeated and violent turnovers of property that had marked the religious wars of the sixteenth and seventeenth centuries. "The state of Ireland, as she had arrived after all of these storms at the start of the eighteenth century, is really without parallel in the history of Europe", Gentz observed. The "single example" in modern history of the "dark and intolerant spirit" of the English reformation in Ireland was to be found in revolutionary France's attempt to "force its new republican Religion, a kind of political Protestantism, on neighbouring states". ${ }^{82}$ What the French revolutionaries and English Protestants had in common was their willingness to sacrifice the rights of property to religious and political enthusiasm. Gentz echoed Duigenan's argument, advanced in the latter's writings against Burke, that the confiscation of Catholic land, and the subsequent restriction of Catholic property and voting rights, were legitimated "not by means of a right of conquest ... but through a series of police and criminal statutes". ${ }^{83}$ But he nonetheless aligned himself with Burke's savage critique of the Penal Laws' operation in eighteenth century Ireland: these, Gentz claimed, had amounted to a perverse attempt to recreate the exclusionary economic system of the Greek city-republics in the conditions of modern Europe. ${ }^{84}$

The rise of commerce and enlightenment, however, held out the prospect that the British connection might at last fulfil its potential in integrating Ireland with the progress of

\footnotetext{
${ }^{81}$ Friedrich Gentz, "Final-Vereinigung", 540-1.

82 Gentz, "Final-Vereinigung", 544.

${ }^{83}$ Ibid., 560. Compare Patrick Duigenan, A Fair Representation of the Present Political State of Ireland (Dublin, 1800), pp.124-25.

${ }^{84}$ Gentz, "Final Vereinigung", 560.
} 
human civilisation. Throughout the eighteenth century, the Penal Laws had been progressively undermined by the gradual diffusion of wealth that Gentz, like Adam Smith, saw as attendant on even the most flawed commercial societies. Noting Ireland's economic renaissance since the middle of the eighteenth century, he claimed that "the prosperity, that this industry created, spread itself unnoticed, to a certain degree, among the oppressed Catholics, after the natural course of things, which the most perverse legislation can disrupt, but never overpower." More importantly, however, the political attitude of the Protestant aristocracy, and the British government, began to be transformed by the progress of Enlightenment. Just as modern doctrines of political economy that had begun to moderate princely ambition and violence on the continent, "sound maxims of state" had begun to soften the attitude of British and Irish élites to the Kingdom's Catholic population. ${ }^{85}$ As proof of the reformed direction of British policy, Gentz listed the lifting of restrictions on trade and Catholic property rights in 1778 , the concession of legislative autonomy in 1782 , the attempts at a trade agreement in 1785, the admission of Catholics to the county franchise in 1793, and the inclusion of Ireland within the Navigation Acts in the same year. ${ }^{86}$

It was the rebel United Irishmen and sympathetic Whigs like Henry Grattan who had fatally undermined a developing consensus around the gradual amelioration of Ireland's aberrant social order. Gentz lifted his contempt for Grattan from Duigenan's writings, and echoed the conspiratorial accounts of the origins of the 1798 rebellion outlined in the 'Secret Reports' of various parliamentary inquiries into the rising. ${ }^{87}$ Irish radicals had incited sectarian tensions in order to sow chaos and advance a democratic form of

\footnotetext{
85 Ibid., 563.

${ }^{86}$ Gentz, "Final-Vereinigung (Beschluss)", 688-9.

${ }^{87}$ Patrick Duigenan, An Answer to the Address of Henry Grattan (Dublin, 1798), Gentz, 'Final-Vereinigung (Beschluss)', Historisches Journal, 4 (1800), 615-710, at 675-88.
} 
tyranny, in which demagogues would hold absolute power. ${ }^{88}$ The repressive legislation and military campaigns used by the British state to secure its control of Ireland in the wake of the 1798 rebellion were nothing more than the defence of property and the state against a "barbarically conducted attempt to found a democratic republic ... with an armed hand". 89 "When such a moment arises," Gentz concluded, "all means are just that are used by a legitimate authority". ${ }^{90}$

A further goal for Gentz's defensive re-casting of Irish history was to separate its widely recognised pathologies from the broader case, scattered across a range of his writings from 1795 onwards, for the progressive potential of conquest and empire. The expansion of territorial states, and the construction of trans-oceanic mercantile empires even through violence, conquest and injustice - could ultimately be justified with reference to the increases in human knowledge, industry and communication that they enabled. Gentz's observations on the impact of the discovery of America sought, in the style of Smith or William Robertson, to demonstrate how the "half-barbarised" conquistadores, motivated by a corrupt desire for gold and silver, had proven the unwitting agents of civilisational progress in Europe. ${ }^{91}$ Of greater relevance to Prussia and Ireland, however, was the history of conquest and state-making within the European continent. "France, Spain, England, Russia" and the "two great monarchies of Germany", he noted, had "once, the whole lot of them, been nothing more than unformed aggregates of ripped-up, fragmentary sovereignties, mixed up in endless internal skirmishes". ${ }^{22}$ The consolidation of the European states-system was the major political achievement of the

\footnotetext{
${ }^{88}$ Gentz, "Final-Vereinigung (Beschluss)"., 581-5.

${ }^{89}$ For a more nuanced view of the political aspirations of the United Irishmen, see most recently Ultan Gillen, "Constructing democratic thought in Ireland in the age of revolution, 1775-1800" in Joanna Innes and Mark Philp (eds.), Re-Imagining Democracy in the Age of Revolutions: America, France, Britain and Ireland, 17501850 (Oxford, 2013), 149-162.

${ }^{90}$ Gentz, "Final-Vereinigung (Beschluss)", 696-7.

${ }^{91}$ Friedrich Gentz, "Ueber den Einfluß der Entdeckung von Amerika auf den Wohlstand und die Cultur des menschlichen Geschlechts", Neue Deutsche Monatsschrift, 2 (1795), 269-319.

92 Gentz, "Frieden", 734-5.
} 
past two centuries. "The tendency to build great states," Gentz wrote in his perpetual peace essay, “does not only arise from rulers' ambition and obsession with power. It is an unavoidable consequence, a natural and beneficial tendency arising from the higher culture of nations". ${ }^{93}$ This was an argument with significant local relevance, given the nature of Prussia's own civilising mission in the Polish territories acquired in the partitions of 1772,1793 , and 1795. Prussian commentators frequently justified the conquest of Poland by arguing that the Prussian state was capable of guaranteeing the civil liberty of ordinary Poles, who had always been oppressed by their proud freedoms of their noble masters. ${ }^{94}$ Gentz had first-hand experience in the administration of the territories gained in 1793, and his history of British government in Ireland, like his essay on perpetual peace, aligned neatly with a contemporary Prussian discourse of selfcongratulation over the transmission of orderly monarchical government to the former Commonwealth. ${ }^{95}$

Gentz's case for Union, however, had more specific institutional components than a general apologia for an enlightened policy of conquest. It outlined the conditions under which the consolidation of territorial states could be expected to result in civil equality and material progress for their subject peoples. As we have seen, his constitutional theory emphasised the ultimate need for unitary sovereign authority, whatever the nature of the specific political régime. This had a spatial, as well as a legal, dimension, without which the civilisational benefits of state expansion and conquest could not be fully realised. In his essay on perpetual peace, Gentz's description of the modern territorial state emphasised the interplay between a powerful and unified sovereignty and the diverse operations of an advanced market economy:

\footnotetext{
93 Ibid., 731.

${ }^{94}$ Otto Tschirch, Geschichte der offentlichen Meinung in Preussen: vom Baseler Frieden bis zum Zusammenbuch des Staates, 2 vols. (Weimar, 1933), 1:155-81.

${ }^{95}$ Zimmermann, Friedrich Gentr, 70, 157.
} 
The more important the matters of legislation, the greater and more diverse the concerns of government become, the more necessary it becomes, that in a great circuit of the earth, the endless divergence of private goals and the private activities of men, and the free play of their powers, are held together in the unity of a highest goal and a highest power. ${ }^{96}$

Gentz endorsed the parliamentary Union of Britain and Ireland as a model of exactly this kind of modern state-formation. He did so on two grounds. In the first instance, he argued that only the durable consolidation of executive and legislative power in a single parliament would permit the new Union-state to function as a dependable vessel for the freedom of commercial exchange. If they were represented by separate assemblies with the ability to pass conflicting laws governing economic activity, individual citizens in Britain and Ireland were at constant risk of being constrained in their commercial transactions by failures of co-ordination. "In the old system", Gentz observed, "the trade relationships between both countries were, even after accomplished agreements, still dependant on the changing maxims and whims of the separated legislatures". ${ }^{97}$

Unlike many British and Irish advocates of Union, including Pitt, Gentz did not offer a rhapsodic account of Ireland's likely economic growth under the conditions of Union. ${ }^{98}$ The argument for rapidly rising Irish prosperity rested on the proposition that free trade between the two countries would encourage British merchants and manufacturers to

\footnotetext{
96 Gentz, "Frieden"., 731.

${ }^{97}$ Gentz, "Final-Vereinigung (Beschluss)", 638.

${ }^{98}$ Josiah Tucker \& Thomas Brooke Clarke, Union or separation, 2nd edn. (London, 1799); William Pitt, Speech of the Right Honourable William Pitt, in the House of Commons, Thursday January 31 st 1799 (London, 1799), pp.4652 made the case in these terms.
} 
invest heavily in Ireland in order to take advantage of the latter's low labour costs. ${ }^{99}$ On this question, Gentz sided with the more modest argument for Union put forward by the Aberdonian MP Sylvester Douglas, a Portland Whig close to Pitt's ministry. Based on a careful reading of the Scottish experience after 1707, Douglas suggested that free trade under a Union would create the conditions for accelerated progress, but offered no guarantees of a rapid capital influx. ${ }^{100}$ "It would be stupidity", Gentz concurred, "to expect that all at once foreign capital would flow into Ireland, from a land, where one knows so well how to use capital, and so rarely lets it lie idle, as in England". ${ }^{101}$ More important was the final and irreversible admission of Irish subjects of the Crown into all the privileges and possibilities of Britain's global commercial empire. Union would act as "a great social contract, through which Ireland is at once incorporated in to the full community of the whole British national property and commerce, through which it conquers the British colonies, and transforms the East and West Indies in to its provinces". ${ }^{102}$

A more significant divergence between Gentz's vision of Union and that of its proponents in the British ministry was signalled by the Prussian's rejection of Catholic Emancipation. ${ }^{103}$ This had a clear basis in Gentz's wider political theory. A key plank of Gentz's counter-revolutionary argument, expressed since his Burke translation of 1793, was that the issue of political representation was a matter of prudence, not of right, since civil, not political, liberty was the purpose of the state as a legal institution. "All the ostentatious declamations about the joys of freedom", Gentz had written in 1799, "were

\footnotetext{
99 Istvan Hont, 'The 'Rich Country-Poor Country' Debate Revisited: The Irish Origins and French Reception of the Hume Paradox', in C. Wennerlind \& M. Schabas (eds.) David Hume's Political Economy (London, 2008), 243-323, at 298-304.

${ }^{100}$ Sylvester Douglas, Speech of the Right Honourable Sylvester Douglas, Relative to a Union with Ireland (London, 1799), p.32. Gentz discusses Douglas' speech at Gentz, "Final-Vereinigung", 606.

${ }^{101}$ Gentz, "Final-Vereinigung (Beschluss)", 643-44.

102 Gentz, "Final-Vereinigung", 537-38.

103 Geoghegan, Irish Act of Union, 26-41; John Bew, Castlereagh: Enligbtenment, War and Tyranmy (London, 2011), 127-29.
} 
only panegyrics to the means to an end, and transform themselves into vain phrases, if this freedom is unable fully to realise its true ultimate end, the unlimited domination of the laws". ${ }^{104}$ Gentz was correspondingly sceptical about the need to address the exclusion of Catholic electors from the borough franchise, from the holding of public offices, and from membership of parliament itself. Since the reforms of 1778 and 1793, Irish Catholics were able to hold property and pursue professions on equal terms with Protestants. Gentz was content to speak of their political disadvantages in terms of "the relatively small evil of a political, rather than a civil, intolerance". ${ }^{105}$ Drawing once again on Duigenan, the staunchest advocate of Union without Emancipation, Gentz sought to demonstrate the extent to which anti-Catholic legislation was interwoven with the constitutive laws of the British state, including the royal succession and the Scottish Union. ${ }^{106}$ The alteration of the confessional character of the British state during an age of revolution was certain to be a risky endeavour. ${ }^{107}$

Gentz's scepticism about Emancipation also had roots in his opposition to the pursuit of what he termed "political equality". The social contract, he asserted, was the best way of legally defining a political society - but it existed to maintain, rather than eliminate, inequalities of property and privilege. To abuse public power to "level" distinctions in modern societies, even where these had themselves been created through prior exercises of sovereignty, was to "destroy the rights of one part of the citizens". ${ }^{108}$ Following an influential line of analysis that ran from Montesquieu via Adam Ferguson and Edmund Burke, Gentz defended a mixed nobility of education, wealth, and title as a vital stabilising influence in modern commercial societies. He lamented that the French

\footnotetext{
104 Gentz, "Staatswissenschaft", 308.

105 Gentz, "Final-Vereinigung", 597.

106 Duigenan, Fair Representation, pp.194-96.

107 Gentz, "Final-Vereinigung"., 596-97.

${ }^{108}$ Friedrich Gentz, "Ueber die politische gleichheit", Historisches Journal, 1 (1800), 1-51, at 7-12.
} 
revolutionaries' irrational exuberance had destroyed the foundation of inequality on which the slow, tangible and irreversible progress of European civilisation had depended: "Social inequalities disappeared, but the step towards a hastened perfection came to nothing; as the the smoke cleared, we found we had been denuded of a great part of the precious means, that had hitherto enabled slow progress, and ensured the impossibility of backsliding". ${ }^{109}$ In an Irish context, these two positions issued in a gradualist approach to the question of Catholic equality. He criticised the Earl of Fitzwilliam, the ill-starred Lord Lieutenant of Ireland who attempted to introduce Emancipation and parliamentary reform without Pitt's authorisation in 1795, for going beyond Burke's principles and advocating revolutionary "political equality" for Irish Catholics. ${ }^{110}$ The route to Catholic liberation was not through an assault on Protestant privileges, but through the slow growth of Catholic landed property, already enabled by the repeal of the Penal Laws. "The Catholics must first become great landowners," Gentz argued, "even to make claims in the future to prerogatives, that in Ireland, as in England, are exclusively linked to territorial property". ${ }^{111}$

\section{FACTION, COUNSEL AND PUBLIC OPINION}

Gentz's analysis of British-Irish Union sought to vindicate a policy of counterrevolutionary conquest as the best means to the pacification of Europe. He argued that the pathologies of empire in Ireland had been resolved through the determined application of state power to protect property and civil liberty, promote the freedom of trade, and violently suppress revolutionary activity. But his essays also had a more

\footnotetext{
109 Ibid., 49-51.

110 Gentz, "Final-Vereinigung", 587. As it happens, Gentz was wrong about this: see Burke's private 'Letter to William Smith', in McDowell (ed.), Writings and Speeches IX, 658-665, a clear endorsement of Fitzwilliam's policy.

111 Ibid., 581.
} 
immediate function: to convince Prussian opinion that the threat to Britain's war-fighting capacity arising from rebellion on its Irish flank would be reduced through the operation of Union with Ireland. As his attribution of the United Irish rising to a republican conspiracy suggested, he regarded the dynamics of Irish politics as being driven by élite factional competition rather than deep-seated agrarian, still less sectarian, discontent. By transforming the institutional context for Anglo-Irish relations, Union therefore had the potential to render Ireland immune to French influence.

This emphasis on the politics of faction also reflected Gentz's criteria for evaluating the effectiveness of Europe's rival political systems. In a contemporaneous memorandum on the government of the Prussian monarchy, he declared himself interested in the "organisation of the highest offices of the state", rather than the "inner administration" of the monarchy's provinces. The major thrust of the programme of top-level reform that Gentz advocated in his capacity as a Prussian official was the removal of the "secret" cabinet of royal secretaries and a return to collegiate administration through the established ministries of state. The "secret cabinet", Gentz declared, was a "deplorable intermediary office" that "suspends, while it claims to direct, the whole operation of the political machine". ${ }^{112}$ These organisational concerns were central to Gentz's broader constitutional theory, which denied a conceptual distinction between the "separation of powers" present in the British or American systems of government and the simple functional division of ministerial functions in the Prussian monarchy. ${ }^{113}$ Whether via representatives of the people or appointed "state-counsellers" of key ministries, the key requirement for effective government was an orderly process of deliberation and sovereign decision, geared towards the successful conduct of foreign policy. ${ }^{114}$

\footnotetext{
112 Wittichen, "Friedrich von Gentz", 249.

113 Gentz, "Theilung der Macht", 125-27.

114 Wittichen, "Friedrich von Gentz", 269.
} 
These priorities were reflected in his examination of the British-Irish Union. Gentz did not devote significant energy to matters of "inner administration", denying that the Union would result in a significant expansion of the tax revenues available to the British war effort. ${ }^{115}$ Indeed, as subsequent historians have noted, one of the ironies of the British-Irish Union was that it instituted complete legislative integration while maintaining a separate Irish fiscal administration, public debt, and currency. ${ }^{116}$ The focus of Gentz's exposition was on the institutional relationships between the Dublin and London parliaments, and the potential of the constitution of 1782 to generate political dynamics that threatened the stability of the Anglo-Irish connection. In common with almost every British and Irish advocate of Union listed among his sources, Gentz argued that the Irish constitution of 1782, under which the Dublin parliament enjoyed what was termed "legislative independence", was dangerous because it created the potential for Irish legislators to act as a semi-detached power within the British state. ${ }^{117}$ Since 1782 , the connection of the British and Irish kingdoms through their shared monarchical executive had produced a particularly flawed iteration of the separation of powers. Irish patriots had allowed the Great Seal of Britain to be used to sanction Irish legislation, in order to preserve the cohesion of the polity while allowing the fiction of Irish "independence" to be sustained. ${ }^{118}$ The means through which the British cabinet maintained this awkward form of political coordination were dangerously unstable, because of the politically toxic character of the foreign system of patronage needed to sustain it. The necessary and legitimate fusion of legislative and executive power that characterised the British constitution became the target of an "egomaniacal" rhetoric of

\footnotetext{
115 Gentz, "Final-Vereinigung (Beschluss)”, 615-23

116 K. Theodore Hoppen, “An Incorporating Union? British Politicians and Ireland 1800-1830", The English Historical Review, 123 (2008), 328-50.

117 Edward Cooke, Arguments for and against an union, between Great Britain and Ireland, Considered (London, 1798), 12, Pitt, Speech, 19-20

118 Gentz, "Final-Vereinigung", 516-17.
} 
patriotic protest that was constantly open to exploitation by Francophile demagogues. "In England," Gentz observed,

the influence of the government on Parliament, in its moderate limits, is a source of power that is inseparable from the constitution, recognised, and woven in to the innards of the state. In Ireland, this influence is necessarily an unconstitutional, secret, and moreover foreign instrument of the government ... hence the restless complaint over British influence, and British corruption, the great battle cry of all instigators of disorder, and all demagogues. ${ }^{119}$

This readily available sense of grievance created a constant incentive for opposition politicians to push Irish parliamentary autonomy to its logical conclusion: the rejection of the British ministry's policies. Gentz offered the acrimonious breakdown of negotiations to secure an Anglo-Irish trade agreement in 1785, and the conflict between the two parliaments over the appointment of a Regency Council following George III's mental breakdown in 1789, as egregious examples of the constitution's ultimate tendency towards total dissolution. Most dangerously of all, however, the dubious legitimacy of an Irish parliament dominated by its British executive had provided the crucial institutional context for the separatist republican rising of 1798. "After Ireland has become an integral part of the British state", Gentz declared, "a great basis, and a powerful means of assistance for all machinations towards separation must fall away". ${ }^{120}$ Union reestablished a workable form of sovereignty in Britain by advancing the fusion of executive and legislative power that was the defining characteristic of its modern constitution. It stripped Ireland of its threatening capacity to reach sovereign decisions

\footnotetext{
119 Ibid., 520-21.

120 Gentz, "Final-Vereinigung (Beschluss)", 699.
} 
that conflicted with those of Westminster, reducing Irish MPs to "an ever-present highest counsel within the common government". ${ }^{121}$

Gentz owed his fame in Berlin's literary circles not just to his translation of Burke, but to a bold written address to the newly-crowned Friedrich Wilhelm III in $1797 .^{122}$ Consciously emulating the younger Mirabeau, who had undertaken a similar exercise on the coronation of Friedrich Wilhelm II in 1786, Gentz lectured the new king on the justice and prudence of abolishing press censorship: "of all things that shun restraint, nothing can bear it less, than the thoughts of men". ${ }^{123}$ The implementation of BritishIrish Union illustrated the political benefits of an unconstrained process of public deliberation over important matters of state. While Gentz's bibliography was designed to buttress the authority of his judgements, it was also used to bear out his opening claim that "a political operation has seldom been debated ... with so much thoroughness and good sense". ${ }^{124}$ He portrayed the successful passage of the Irish Act of Union through the Dublin parliament as arising from the true "general will ... among the class of people capable of a decision, the educated, who alone are suited to judgment, through standing, position and knowledge". ${ }^{125}$

Perhaps surprisingly, Gentz was a close and admiring reader of Jean-Jacques Rousseau, and was aware of the provenance of the idea of a "general will" in the latter's Social Contract (1761). ${ }^{126}$ His embrace of public opinion echoed Kant's reworking of the idea of

\footnotetext{
121 Gentz, "Final-Vereinigung”, 525.

122 Zimmermann, Friedrich Gentz, pp.113-18.

${ }^{123}$ Friedrich Gentz, Seiner Königliche Majestät Friedrich Wilhelm dem III. (Berlin, 1797), 30. Gentz's tolerance did not extend to writings that suggested active disobedience to state authority: Wittichen, "Das preussische Kabinett und Friedrich von Gentz", 263.

124 Gentz, "Final-Vereinigung", 504.

125 Ibid., 503.

126 Gentz, "Staatswissenschaft", 279-80.
} 
the social contract in his essay on "Theory and Practice" (1793). Here, Kant had dispensed with Rousseau's insistence on periodic popular assemblies to prevent sovereign authority from descending into a tyranny of private wills. He redefined the social contract as an "idea of reason" that could "oblige every legislator to frame his laws in such a way that they could have been produced by the united will of a whole nation". ${ }^{127}$ Abuses of power were to be corrected not by the dangerous chimera of a right of resistance, but by the operation of public opinion under what Kant termed the "freedom of the pen". The free provision of information regarding the "consequences of the laws which the supreme authority has made" made it possible for the sovereign to discern if they really could have been acts of a public will. ${ }^{128}$ As we have seen, Kant coupled this conception of public opinion with a relatively expansive idea of representative government and the separation of powers in his mature political theory. ${ }^{129}$ Gentz's interest in Prussian administrative reform, along with his restriction of the "general will" to the propertied and educated, suggested a parallel route to the incorporation of a form of public opinion into the practice of enlightened sovereignty.

As such, the development of effective systems of deliberation and decision was not only a matter of administrative efficiency. Gentz's proposal for the installation an overarching council of state to displace the "secret cabinet" from its dangerous position of influence paralleled his endorsement of Britain's elimination of factional politics from the government of Ireland. In both cases, he sought to construct an extensive process of deliberation among representatives of sovereign authority, which operated in conjunction with public opinion to ensure that the operations of government ultimately conformed to a public will. This enabled him to re-fashion Kant's modern republicanism into a

\footnotetext{
${ }^{127}$ Kant, “Theory and Practice", p.79.

128 Ibid., pp.84-5.

${ }^{129}$ On Kantian public opinion as a form of continuous representation, see Reidar Maliks, "Acting Through Others: Kant and the Exercise View of Representation", Public Reason, 1 (2009), 9-26.
} 
political theory that was far more amenable to the legitimation of Europe's existing systems of government. The secretive character of sovereign authority, historically the source of so much of its danger and arbitrariness, could be softened through the action of counsel and publicity. A complex separation of powers was not necessary to achieve a system of government that accorded, as far as was practically possible, with the principles of public right. Indeed, as we have seen, Gentz believed that institutional reform of this nature risked the paralysis of responsible political agency. Gentz wrote in his critique of mixed constitutions that "a single man can often be a truer and more just representative of the general will ... than five hundred lawmakers." ${ }^{130}$ It was through an extensive process of discussion among the educated that a unitary system of sovereignty could be educated, rather than constrained, to avoid arbitrary excesses of power.

\section{MODERN LIBERTY AND UNIVERSAL HISTORY}

Gentz's invocation of truth and justice as defining attributes of sovereignty invites reflection on the moralised, and moralising, character of the state personality developed in his alternative to perpetual peace. The recent work of Isaac Nakhimovsky has done much to dispel older interpretations that saw Kant and Gentz as representing an eternal binary opposition between "idealist" and "realist" accounts of international relations. Gentz's essays on the Union illustrate the strong normative thrust that underpinned his extensive empirical study of the theory and history of the state in eighteenth century Europe. Kant had ultimately advocated fundamental reforms to European states and the relations between them in order to better align politics with the imperatives of human moral development outlined in his "Idea for a Universal History" (1784). For Gentz, the French revolution was ultimately the product of a particularly vain and stupid attempt to

\footnotetext{
${ }^{130}$ Gentz, “gemischten Staatsverfassungen”, 490.
} 
"hasten" (beschleunigen) the perfection of human capacities, seeking "through boldness and violence to achieve in a moment, what the nature of the human species only step by step, and under the eternal conditions of law and wisdom, had ordained". ${ }^{131}$

Powerful, but benevolent, Britain was the European power that best embodied the enlightened reason of state that Gentz advocated as the alternative to revolution and perpetual peace. The essays on Union encouraged Prussian identification with Britain by advancing a particular vision of its character and likely future. As we have seen, they proclaimed the British state's capacity to exercise a modern, integrative and inclusive form of empire over a poor and divided neighbour, just as Prussia was doing through its administration of conquered Poland. Through his examination of the British political system, Gentz explored how the imperatives of conquest and civilisation could be reconciled with the just and orderly exercise of sovereign authority. In doing so, he asserted that the commercial monarchies and balance of power developed in the course of the eighteenth century remained the best available vessels for the further progress of mankind.

The two forms of ancient republican liberty that continued to inspire many European reflections on modern politics, the participation of citizens in lawmaking, and the maintenance of the independence of historic political communities, therefore played almost no part in Gentz's thought. ${ }^{132}$ While Gentz claimed to regret the partition of Poland as a violation of the law of nations, he did not seek a revival of the Commonwealth that had inspired Rousseau's most extensive reflections on the

131 Gentz, "Frieden", 787.

132 Whatmore, Against W ar and Empire. 
preservation of ancient forms of freedom in the conditions of modern Europe. ${ }^{133}$ The future of Europe lay in the development of civil, not political, liberty; and the advancement of modern liberty could provide ample justification for certain kinds of conquest and empire. National independence was a negotiable good. "The true independence of citizens and the nation", he wrote of Ireland, "will be increased, not reduced, through the combination of parliaments; this true independence hangs from the progress of culture, and the freedom of trade". ${ }^{134}$ Because more expansive and effective forms of state sovereignty were essential to the further development of the human species, the Irish Acts of Union were a rare progressive development in the devastated landscape of post-revolutionary Europe.

Whatever the merits of this particular vision of the founding moment of the modern United Kingdom, Gentz's essays therefore retain a distinct historiographical interest for historians of Britain and Ireland, as well as of political thought. As a previously unexplored European source on the ideological significance of the British-Irish Union, they show us that this important moment in "British" history could readily be integrated into political languages and debates that encompassed, but transcended, the British Isles and the "British Atlantic World". Further efforts to position Union within these might open up new perspectives on its meaning at the turn of the nineteenth century, tying it not only to expressions of British and Irish identities, but to specific and contested forms of knowledge about politics, morality, economics and law. Efforts have long been underway to place the Anglo-Scottish Union of 1707 in this broader conceptual and

\footnotetext{
133 Friedrich Gentz, On the State of Europe Before and After the French Revolution, (London, 1802), 82-3; JeanJacques Rousseau, "Considerations on the Government of Poland", in Victor Gourevitch (ed.), The Social Contract and other later political writings (Cambridge, CUP), 177-261.

134 Gentz, “engern Vereinigung”, 482.
} 
geographical perspective, and this enterprise has an obvious contemporary resonance. ${ }^{135}$ By exploring the position of the British-Irish Union of 1801 in the contemporaneous writings of a leading Prussian political thinker, this article has sought to develop one perspective on its position within European theories of the state, commercial society and international relations in the age of the French Revolution. In showing us the Union out of local context, Gentz offers a route to renewed understanding of its underlying significance.

135 Colin Kidd, Union and Unionisms: Political Thought in Scotland, 1500-2000 (Cambridge, 2008); John Robertson (ed.), A Union For Empire: Political Thought and the British Union of 1707 (Cambridge, 1995). 